\title{
The Effect Of International Financial Reporting Standards Convergence On U. S. Accounting Curriculum
}

Homer L. Bates, University of North Florida, USA

Bobby E. Waldrup, University of North Florida, USA

Vincent Shea, St. Johns University, USA

\begin{abstract}
Major changes are coming to U.S. financial accounting and accounting education as U. S. generally accepted accounting principles (GAAP) and international financial reporting standards (IFRS) converge within the next few years. In 2008, the U.S. Securities and Exchange Commission (SEC) published a proposed "road map" for the potential convergence of $U$. $S$. companies to IFRS beginning with large filers for fiscal years ending on or after December 15, 2014. On February 24, 2010, the SEC issued a new timeline which would require IFRS for U.S. reporting in 2015 or 2016 at the earliest (Derstine and Bremser, 2010). Obviously, this change to IFRS requires an adjustment in U. S. accounting education. The primary purpose of this paper is to examine the current state of accounting curricula and IFRS. An examination was made of both required and elective international accounting courses offered to students in the top 20 undergraduate, graduate and doctoral programs. These programs were identified by the Public Accounting Report in its October 31, 2009 issue. It was conjectured that the top programs would take the lead in IFRS education. The universities' online websites and catalogues were examined for program requirements and course titles. The results show a paucity of accounting coursework related to international accounting and IFRS.
\end{abstract}

Keywords: U.S. GAAP; IFRS; international; accounting; universities

\section{INTRODUCTION}

n 2000, the SEC sought comments on a concept release on international accounting standards. The U. S. rule-making body, the Financial Accounting Standards Board (FASB) and the International Accounting Standards Board (IASB) initiated a convergence process in 2002 with the goal of a single set of highquality global accounting standards. FASB and the IASB committed to work together to minimize and, if possible, eliminate differences between U.S. GAAP and IFRS. In 2008, the SEC issued a proposed road map to a single set of standards. The SEC provided an update in 2010 continuing to support convergence with a proposed adoption date of 2014 to 2015 .

The attempt at setting a single set of standards for the entire international accounting community has been in motion for over 40 years. The International Accounting Standards Committee was formed in 1973 and evolved into the IASB in 2001. European accounting regulators pushed for the creation of international standards to coincide with the creation of the European Union. The European Union adopted IFRS in 2005 with Australia, New Zealand, China, Korea, Israel, India, Canada, Japan and nearly 100 other countries also adopting IFRS (Thomas, 2009).

In 2010, the American Institute of Certified Public Accountants (AICPA) announced that IFRS would be included on the Certified Public Accounting (CPA) exam beginning in January 2011. In order to make sure that CPA's have a basic understanding of IFRS, there are IFRS questions in three sections of the CPA exam. The fourth 
section, Regulations, will not have IFRS questions (DeFelice, 2010). It is apparent that accounting students must be knowledgeable of IFRS in order to become CPAs and in order to practice. The article will describe the changes in accounting curricula brought about by IFRS in the top 20 U.S. accounting programs.

Table 1: Top Accounting Programs

\begin{tabular}{|c|c|c|c|c|c|c|}
\hline 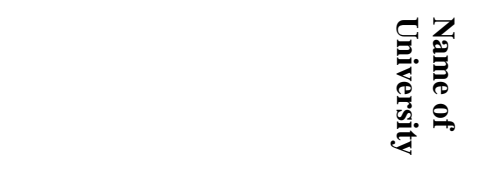 & 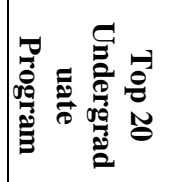 & 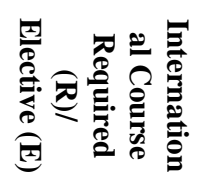 & 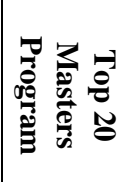 & 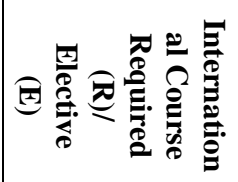 & 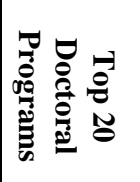 & 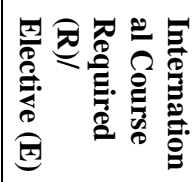 \\
\hline Arizona State University & $\mathrm{X}$ & None & $\mathrm{X}$ & None & & \\
\hline $\begin{array}{l}\text { Baruch College - The City University } \\
\text { of New York }\end{array}$ & & & $\mathrm{X}$ & None & & \\
\hline Brigham Young University & $\mathrm{X}$ & None & $\mathrm{X}$ & $\mathrm{E}$ & & \\
\hline University of Chicago & & & & & $\mathrm{X}$ & None \\
\hline Cornell University & & & & & $\mathrm{X}$ & None \\
\hline University of Florida & $\mathrm{X}$ & None & $\mathrm{X}$ & $\mathrm{E}$ & & \\
\hline University of Georgia & $\mathrm{X}$ & $\mathrm{E}$ & $\mathrm{X}$ & $\mathrm{E}$ & $\mathrm{X}$ & None \\
\hline Harvard University & & & & & $\mathrm{X}$ & None \\
\hline University of Illinois & $\mathrm{X}$ & $E$ & $\mathrm{X}$ & $\mathrm{E}$ & $\mathrm{X}$ & None \\
\hline Indiana University & $\mathrm{X}$ & None & $\mathrm{X}$ & None & $\mathrm{X}$ & None \\
\hline University of Iowa & & & & & $\mathrm{X}$ & None \\
\hline Massachusetts Institute of Technology & & & & & $\mathrm{X}$ & None \\
\hline Miami University (Ohio) & $\mathrm{X}$ & $\mathrm{E}$ & & & & \\
\hline University of Michigan & & & $\mathrm{X}$ & None & $\mathrm{X}$ & None \\
\hline Michigan State University & $\mathrm{X}$ & None & $\mathrm{X}$ & $\begin{array}{c}\mathrm{R} \text { in } 2 \\
\text { Specialties }\end{array}$ & $\mathrm{X}$ & None \\
\hline University of Mississippi & $\mathrm{X}$ & None & $\mathrm{X}$ & $\mathrm{E}$ & & \\
\hline University of Missouri & $\mathrm{X}$ & None & $\mathrm{X}$ & $E$ & & \\
\hline New York University & & & & & $\mathrm{X}$ & None \\
\hline $\begin{array}{l}\text { University of North Carolina at Chapel } \\
\text { Hill }\end{array}$ & & & $\mathrm{X}$ & $\mathrm{E}$ & $\mathrm{X}$ & None \\
\hline Notre Dame University & $\mathrm{X}$ & $\mathrm{E}$ & $\mathrm{X}$ & None & & \\
\hline Ohio State University & $\mathrm{X}$ & None & $\mathrm{X}$ & None & $\mathrm{X}$ & None \\
\hline Penn State University & $\mathrm{X}$ & None & & & $\mathrm{X}$ & None \\
\hline University of Pennsylvania & & & & & $\mathrm{X}$ & None \\
\hline University of Southern California & $\mathrm{X}$ & None & $\mathrm{X}$ & $\mathrm{E}$ & $\mathrm{X}$ & None \\
\hline Stanford University & & & & & $\mathrm{X}$ & None \\
\hline University of Texas - Austin & $\mathrm{X}$ & None & $\mathrm{X}$ & $\mathrm{E}(2)$ & $\mathrm{X}$ & None \\
\hline Texas A \& M University & $\mathrm{X}$ & $\mathrm{E}$ & $\mathrm{X}$ & $\mathrm{R}$ & $\mathrm{X}$ & None \\
\hline University of Virginia & $\mathrm{X}$ & $E$ & $\mathrm{X}$ & None & & \\
\hline Wake Forest University & $\mathrm{X}$ & $\mathrm{E}$ & & & & \\
\hline University of Washington & $\mathrm{X}$ & None & $\mathrm{X}$ & $\mathrm{E}(2)$ & $\mathrm{X}$ & None \\
\hline University of Wisconsin - Madison & $\mathrm{X}$ & None & $\mathrm{X}$ & None & & \\
\hline
\end{tabular}

Source: Public Accounting Report's $28^{\text {th }}$ Annual Professor's Survey - 2009

\section{METHODOLOGY}

The authors theorize that the top accounting programs will take the lead in integrating IFRS into their curricula. Therefore, the top accounting programs were examined to determine whether they had an international or IFRS course in their curricula and whether the course was required or elective. IFRS courses were identified as those that had IFRS, International, Multinational, or Global in their titles. The top 20 accounting programs were identified by using the survey results published in the October 31, 2009 issue of Public Accounting Report. The Report uses faculty surveys to identify the top 25 undergraduate, graduate and doctoral programs. The top 20 programs are shown in Table 1. The top three undergraduate programs were at the University of Illinois at Urbana 
Champaign, the University of Texas - Austin, and Brigham Young University; the top graduate programs were the same three schools with a different order - the University of Texas-Austin, the University of Illinois at Urbana Champaign, and Brigham Young University. The top three research doctoral programs were the University of Texas - Austin, the University of Chicago and Stanford University.

\section{RESULTS}

In addition to listing the schools surveyed, Table 1 also indicates whether the accounting program offered an international course and, if offered, whether the course was elective or required. Table 2 lists the titles of the courses.

Table 2: International Accounting Course Offerings* At Top Accounting Programs

\begin{tabular}{|c|c|}
\hline & Undergraduate Programs \\
\hline \multicolumn{2}{|l|}{ Required Courses: } \\
\hline University of Georgia & Accounting Information in a Multinational Setting ( 3 credit hours) \\
\hline University of Illinois & Introduction to Internal Accounting ( 3 credit hours) \\
\hline Miami University (Ohio) & Survey of International Accounting and Reporting (1 credit hour) \\
\hline Notre Dame University & International Accounting ( 3 credit hours) \\
\hline Texas A \& M University & International Accounting ( 3 credit hours) \\
\hline University of Virginia & International Finance and Accounting ( 3 credit hours) \\
\hline Wake Forest University & International Accounting ( 3 credit hours) \\
\hline \multicolumn{2}{|r|}{ Master's Programs } \\
\hline \multicolumn{2}{|l|}{ Required Courses } \\
\hline Michigan State University & Management Accounting in Global Enterprises ( 3 credit hours) \\
\hline Texas A \& M University & International Accounting ( 3 credit hours) \\
\hline \multicolumn{2}{|l|}{ Elective Courses } \\
\hline Brigham Young University & International Accounting and Multinational Enterprises ( 3 credit hours) \\
\hline University of Florida & International Accounting Issues ( 2 credit hours) \\
\hline University of Georgia & International Accounting (1.5 hours) \\
\hline University of Illinois & Multinational Enterprise Accounting (4 credit hours) \\
\hline Michigan State University & Management Accounting in Global Enterprises ( 3 credit hours) \\
\hline University of Mississippi & International Accounting ( 3 credit hours) \\
\hline University of North Carolina at Chapel Hill & Global Immersion (3 credit hours) \\
\hline Notre Dame University & International Financial Reporting Standards ( 2 credit hours) \\
\hline University of Southern California & Accounting for the Global Business Environment (3 credit hours) \\
\hline \multirow[t]{2}{*}{ University of Texas - Austin } & International Accounting Policies and Procedures (Variable credit hours) \\
\hline & International and European Accounting Standards (Variable credit hours) \\
\hline \multirow[t]{2}{*}{ University of Washington } & Issues in International Accounting (4 credit hours) \\
\hline & Business and International Taxation (4 credit hours) \\
\hline \multicolumn{2}{|r|}{ Doctoral Programs } \\
\hline None & \\
\hline
\end{tabular}

As shown in Table 1, none of the top 20 undergraduate programs required an international accounting course and just seven offered an elective course. At the Masters level, two programs had required courses, Michigan State University and Texas A \& M University. At Michigan State University the international course is required for just two of their four specialties - Financial Reporting and Assurance Services and Management Accounting. Twelve Masters Programs offered elective courses in the international accounting field with the University of Texas - Austin and the University of Washington each offering two elective courses. At the doctoral level there were no required or elective offerings in international accounting. 


\section{CONCLUSION, IMPLICATIONS, AND FUTURE RESEARCH}

The lack of international offerings at the top accounting programs was truly surprising. The premier accounting programs do not appear to be preparing students for the eventual change to international accounting standards. The reasons for this apparent lack of action may be varied. Accounting programs may be covering IFRS in existing courses and may not perceive a need for a separate stand alone course. This could be determined by a survey of the chairs of the top 20 undergraduate, masters, and doctoral universities asking in what courses IFRS is covered and what was deleted in these courses in order to add IFRS coverage. Accounting programs at public universities may be constrained by state laws. In the state of Florida, for example, public universities need special permission to require more than 120 semester hours for an undergraduate degree. Public university accounting programs in Florida would have to change their curriculum by deleting a course in order to add an international or IFRS accounting course.

Regardless of the rationale, changes in accounting curricula should be made immediately and may involve a combined GAAP/IFRS curriculum or a separate GAAP/IFRS curriculum. Accounting students must begin graduating with substantial international accounting knowledge.

\section{AUTHOR INFORMATION}

Homer Bates has been a Professor of Accounting in the Coggin College of Business at the University of North Florida in Jacksonville for the past 26 years. He received his BS and MBA degrees from Indiana University and his $\mathrm{PhD}$ from the University of Illinois. He is an Indiana CPA. His current teaching areas are financial and managerial accounting. He has published in The CPA Journal, the Journal of Accountancy, Business Horizons, California Management Review, and other journals.

Bobby Waldrup is Associate Dean and an Associate Professor of Accounting in the Coggin College of Business at the University of North Florida in Jacksonville. He has published in The CPA Journal, Strategic Finance, Journal of Information Systems, and other journals. He holds a PhD from the University of Mississippi and is a CPA.

Vincent Shea is an Assistant Professor of Accounting at St John's University in Queens, NY. He received his BBA and MBA degrees from the University of North Florida and his PhD from Kent State University. He is a Florida CPA. His current teaching areas are managerial accounting and accounting information systems. He has published in the Journal of Information Systems, The CPA Journal, and other journals.

\section{REFERENCES}

1. DeFelice, A. (2010). CPA Exam to Undergo an Evolution. Journal of Accountancy, 209 (5): 54-58.

2. Derstine, R.P., \& W.G. Bremser. (2010). The Journey Toward IFRS in the United States. The CPA Journal, 80 (7): 6-9.

3. Thomas, J. (2009). Convergence: Businesses and Business Schools Prepare for IFRS. Issues in Accounting Education, 24 (3): 369 - 377. 